\title{
Prevalence and pathology of lungworm infection in bottlenose dolphins Tursiops truncatus from southwest Florida
}

\author{
D. A. Fauquier ${ }^{1, *}$, M. J. Kinsel ${ }^{2}$, M. D. Dailey ${ }^{3}$, G. E. Sutton ${ }^{1}$, M. K. Stolen ${ }^{4}$, \\ R. S. Wells ${ }^{1,5}$, F. M. D. Gulland ${ }^{3}$ \\ ${ }^{1}$ Mote Marine Laboratory, 1600 Ken Thompson Parkway, Sarasota, Florida 34236, USA \\ ${ }^{2}$ University of Illinois Zoological Pathology Program, 2160 S. First Ave., Maywood, Illinois 60153, USA \\ ${ }^{3}$ The Marine Mammal Center, 2000 Bunker Rd., Fort Cronkhite, Sausalito, California 94965, USA \\ ${ }^{4}$ Hubbs-SeaWorld Research Institute, 6295 Sea Harbor Dr., Orlando, Florida 32821, USA \\ ${ }^{5}$ Chicago Zoological Society, c/o Mote Marine Laboratory, 1600 Ken Thompson Parkway, Sarasota, Florida 34236, USA
}

\begin{abstract}
Parasitism of the respiratory system is a relatively common finding in stranded cetaceans; however, no systematic investigations regarding the severity, distribution, and clinical consequences of these infections in bottlenose dolphins Tursiops truncatus have been conducted previously. The present study determined the prevalence of lungworm infections in dead stranded $(\mathrm{n}=$ 22) and live bottlenose dolphins $(\mathrm{n}=44)$ from southwestern Florida, USA, during the period from 2003 to 2005. Dead stranded bottlenose dolphins were necropsied and lungs were examined visually, by palpation, and histologically for lesions consistent with verminous pneumonia. When present, nematodes were counted, measured, and identified to species based upon their morphology. Dolphin feces and blowhole swabs were collected and examined for nematode larvae. Lungworm prevalence was $77 \%$ in dead animals $(n=22)$. The lesions in most cases were mild, chronic, and not the primary cause of death. Only $13 \%$ of dead animals examined had patent infections, with larvae present in blowhole and fecal cytology, and only $18 \%$ of animals had intact worms present at necropsy, with a geometric mean intensity of infection of 22.6 worms animal ${ }^{-1}$. Intact worms were identified as either Halocercus lagenorhynchi or Skrjabinalius cryptocephalus. The highest prevalence of active infections was found in neonates and calves, including 1 stillborn calf. For free-ranging animals, all blowhole swabs $(n=44)$ were negative, and fecal cytology $(n=22)$ showed a $3 \%$ prevalence of patent infection. Findings from the present study support the theory that bottlenose dolphins can be infected transplacentally by lungworms. The impact that such infections may have on neonatal survival is unknown; however, these infections could increase neonatal mortality.
\end{abstract}

KEY WORDS: Lungworm · Bottlenose dolphin · Nematode · Transplacental infection · Florida • Tursiops truncatus

Resale or republication not permitted without written consent of the publisher

\section{INTRODUCTION}

Parasitism, especially of the respiratory or gastrointestinal system, is relatively common in stranded cetaceans and has been documented in animals from the North Sea, eastern Pacific Ocean, and Atlantic Ocean (Baker 1992, Cornaglia et al. 2000, Parsons \& Jefferson 2000, Jauniaux et al. 2002). Lungworm infections associated with stranding or mortality have been documented in harbor porpoises Phocoena phocoena, striped dolphins Stenella coeruleoalba, and finless porpoises Neophocaena phocaenoides (Cornaglia et al. 2000, Parsons \& Jefferson 2000, Siebert et al. 2001). Dailey (1985) suggested that lungworms could be a major mortality factor for cetacean populations. Although lungworms have been documented in stranded cetaceans, systematic investigation regarding severity, 
distribution, and clinical consequences has generally been lacking. A few studies investigating lungworm infection in harbor porpoises have documented the prevalence and distribution of infection with Halocercus invaginatus, Pharurus convolutus, Pseudalius inflexus, Stenurus minor, and Torynurus convolutus (Arnold \& Gaskin 1975, Dailey \& Stroud 1978, Balbuena et al. 1994, Faulkner et al. 1998); however, similar work has not been performed for bottlenose dolphins Tursiops truncatus.

Two species of Halocercus have been reported in bottlenose dolphins, $H$. lagenorhynchi and $H$. delphini (Measures 2001). How parasitism may relate to stranding, morbidity, and mortality has yet to be ascertained. The life cycle of Halocercus spp. is unknown. Various modes of transmission may exist, including use of intermediate hosts such as prey species, or direct transmission of larvae via transplacental or transmammary routes. Dailey et al. (1991) found adult H. lagenorhynchi in neonatal bottlenose dolphin calf lungs in Florida waters, implying prenatal infection can occur. The effect of prenatal infection on perinatal mortality is unknown, as is the prevalence of Halocercus spp. infection in different host age and sex classes.

The present study investigated the prevalence of lungworm infection in bottlenose dolphins from southwestern Florida. Our goals were to determine the lungworm species and life-cycle stages in affected dolphins, to document the gross and histological characteristics of acute and chronic lungworm infection in dolphins, and to the determine the prevalence of patent lungworm infection in the dolphin population residing in Sarasota Bay, Florida, USA, collected opportunistically during health assessment studies.

\section{MATERIALS AND METHODS}

Dead stranded bottlenose dolphins Tursiops truncatus were recovered from southwestern Florida, USA (Pinellas, Manatee, Sarasota, Charlotte, and Lee Counties). At necropsy, sex and body condition were assessed through standard morphometrics. Animals were necropsied within $24 \mathrm{~h}$ of stranding using standard techniques described by Geraci \& Lounsbury (1993) and Rowles et al. (2001). Teeth were collected for age determination by growth layer count from nonknown-age animals according to Hohn et al. (1989).

In addition to standard necropsy procedures, lungs were examined visually and by palpation for lesions consistent with verminous pneumonia. Major airways were opened and examined macroscopically for worms. All nematodes found were collected and fixed in glycerin-alcohol (1 part glycerin and 3 parts 95\% ethanol). Nematodes were counted, measured, and had morphologic examinations performed using a compound microscope. Worms were identified to species level by the criteria of Delyamure (1955) and Anderson (1978). The locations of nematodes within the lung were classified as follows: trachea, bronchi, left parenchyma, and right parenchyma. For each location the species, age, sex, and number of worms present were recorded. Dolphin feces were collected at necropsy and examined for nematode eggs and larvae. A $5 \mathrm{~g}$ sample of feces was strained with $50 \mathrm{ml}$ of a detergent/water mixture through 2-ply gauze and allowed to sediment for from 10 to $20 \mathrm{~min}$, and then a subsample of sediment was placed on a clean microscope slide. Additionally, blowhole swabs and tracheal swabs were collected on sterile cotton swabs for microscopic examination of larvae. Swabs were rolled onto clean microscope slides in a drop of sterile saline and stained with methylene blue. Parasite larvae were identified using the criteria of Delyamure (1955).

For histopathological analysis, the right and left lungs from fresh animals were transversely divided ('bread loafed') into 10 equal portions. Directed sampling of affected lung was performed as follows: verminous lesions were given a subjective determination of active or chronic based on gross appearance. Active lesions were characterized as nodules $>5 \mathrm{~mm}$ with intact worms present in the nodules or in the bronchi or bronchioles. Chronic lesions were characterized as nodules $<5 \mathrm{~mm}$ with only lungworm remnants present in the lesions. Representative samples from up to 2 areas of each lesion designation (up to 6 samples) were collected for histological evaluation. Randomized sampling was also employed to survey for other pulmonary pathology and/or grossly undetectable verminous pneumonia lesions. Serial sections of each lung were numbered from 1 to 10 , from cranial to caudal areas; 5 sections were selected at random and samples were collected. Samples incorporated bronchi, bronchioles, or parenchyma distant from conducting airways, with the selection of the particular sample type randomized. Finally, representative samples of all organ systems were collected from fresh animals to survey for concurrent diseases and to assist in cause of death analysis as part of a comprehensive postmortem evaluation. All tissues were fixed in $10 \%$ neutral buffered formalin and submitted to the University of Illinois Zoological Pathology Program for evaluation.

Additionally, free-ranging bottlenose dolphins were sampled during health assessment studies conducted by the Sarasota Dolphin Research Program (Wells et al. 2004). Blowhole swabs and feces were collected from animals briefly captured in February and June 2004 and in February and June 2005, and processed as previously described. 


\section{RESULTS}

Twenty-two dead stranded bottlenose dolphins Tursiops truncatus were recovered between 1 September 2003 and 1 July 2005 in the study area (13 males and 9 females; Table 1). Animals were separated into age categories and stage of maturity based upon age determination from growth layer counts of teeth (Hohn et al. 1989) or upon standard length ranges (Read et al. 1993) if teeth were not available. There were 3 neonates $(<125 \mathrm{~cm} ; 0$ to $0.1 \mathrm{yr}), 7$ calves $(<205 \mathrm{~cm} ; 0.3$ to $3 \mathrm{yr})$, 3 subadults ( 200 to $238 \mathrm{~cm} ; 4.5$ to $13 \mathrm{yr}$ ), and 9 adults ( $>240 \mathrm{~cm}$; 14 to $34 \mathrm{yr}$ ).

Gross postmortem examinations were conducted on all animals. Of the 22 animals examined grossly, 17 ( $77 \%$ ) had hard, 5 to $20 \mathrm{~mm}$ yellow nodules present in the lungs. On cut-section these nodules had caseous debris with lungworm remnants present, indicating previous lungworm infection. In addition, of the 22 animals examined grossly, 4 males (MML 0331, MML 0503, MML 0507, MML 0510) had an active lungworm infection, with intact worms present in the lungs and bronchi (Fig. 1A, B). Of the 4 animals with active infections, 3 were neonates or calves.

Histological examination was performed on 15 of the 22 animals $(68 \%)$. Histopathology was not performed on the remaining 7 animals due to moderate to severe
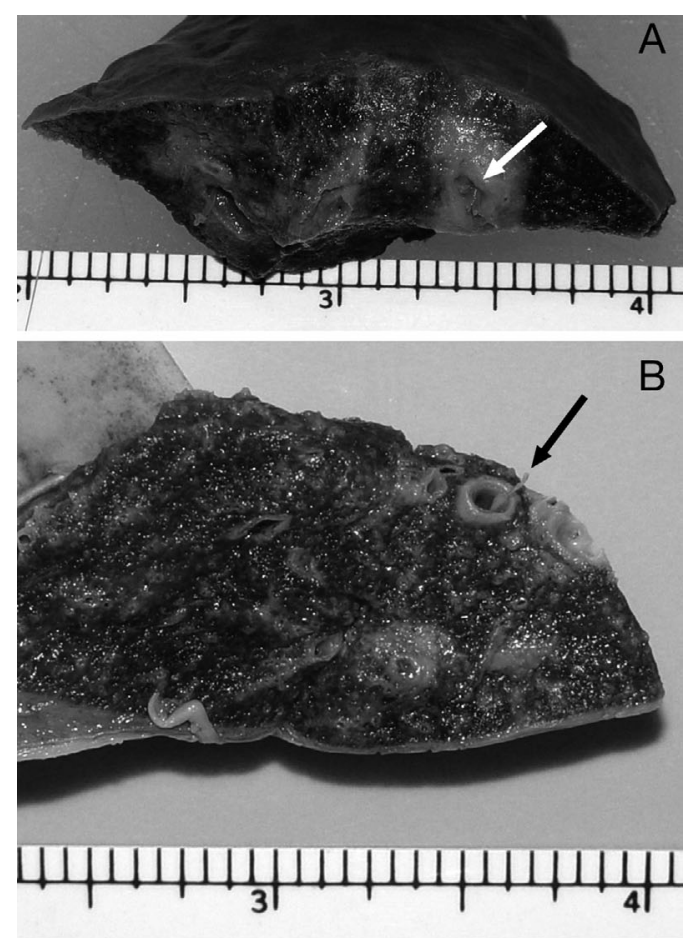

Fig. 1. Tursiops truncatus. (A) Lungworm in lung tissue nodule/abscess (white arrow, MML 0501). (B) Lungworm in terminal bronchus (black arrow, MML 0503). Scales in centimeters below figures

Table 1. Tursiops truncatus. Bottlenose dolphin stranding data. LW: lungworm; M: male; F: female; Y: yes; N: no; NA: not applicable

\begin{tabular}{|c|c|c|c|c|c|c|c|c|c|}
\hline Field ID & Sex & $\begin{array}{l}\text { Size } \\
(\mathrm{cm})\end{array}$ & $\begin{array}{l}\text { Age } \\
(\mathrm{yr})\end{array}$ & $\begin{array}{c}\text { Age } \\
\text { category }\end{array}$ & Strand date & $\begin{array}{c}\text { LW } \\
\text { nodules on } \\
\text { postmortem }\end{array}$ & $\begin{array}{c}\text { LW } \\
\text { positive } \\
\text { based on } \\
\text { histopathology }\end{array}$ & $\begin{array}{l}\text { LW } \\
\text { present in } \\
\text { bronchi }\end{array}$ & $\begin{array}{l}\text { Minimum } \\
\text { no. of } \\
\text { intact LW }\end{array}$ \\
\hline MML 0408 & $\mathrm{M}$ & 102 & 0 & Neonate & 6 May 2004 & $\mathrm{~N}$ & $\mathrm{Y}$ & $\mathrm{N}$ & 0 \\
\hline MML 0510 & $\mathrm{M}$ & 122 & 0 & Neonate & 8 Apr 2005 & $\mathrm{~N}$ & $\mathrm{Y}$ & $\mathrm{Y}$ & 11 \\
\hline MML 0331 & $\mathrm{M}$ & 116 & 0.1 & Neonate & 28 Sep 2003 & $\mathrm{Y}$ & $\mathrm{Y}$ & $\mathrm{Y}$ & 59 \\
\hline MML 0506 & $\mathrm{~F}$ & 134 & 0.3 & Calf & 17 Feb 2005 & $\mathrm{Y}$ & $\mathrm{Y}$ & $\mathrm{N}$ & 0 \\
\hline MML 0338 & $\mathrm{M}$ & 162 & 1.5 & Calf & 29 Nov 2003 & $\mathrm{Y}$ & $\mathrm{Y}$ & $\mathrm{N}$ & 0 \\
\hline MML 0336 & $\mathrm{~F}$ & 183 & 1.5 & Calf & 15 Nov 2003 & $\mathrm{Y}$ & NA & $\mathrm{N}$ & 0 \\
\hline MML 0339 & $\mathrm{M}$ & 190 & 1.5 & Calf & 13 Dec 2003 & $\mathrm{Y}$ & $\mathrm{Y}$ & $\mathrm{N}$ & 0 \\
\hline MML 0503 & $\mathrm{M}$ & 186 & 3 & Calf & 5 Feb 2005 & $\mathrm{Y}$ & $\mathrm{Y}$ & $\mathrm{Y}$ & 45 \\
\hline MML 0404 & $\mathrm{M}$ & 200 & NA & Calf & 2 Mar 2004 & $\mathrm{Y}$ & $\mathrm{Y}$ & $\mathrm{N}$ & 0 \\
\hline CMA 0401 & $\mathrm{M}$ & 204 & NA & Calf & 2 Jan 2004 & $\mathrm{Y}$ & $\mathrm{Y}$ & $\mathrm{N}$ & 0 \\
\hline MML 0504 & $\mathrm{~F}$ & 235 & 4.5 & Subadult & 6 Feb 2005 & $\mathrm{Y}$ & NA & $\mathrm{N}$ & 0 \\
\hline MML 0501 & $\mathrm{M}$ & 200 & 6 & Subadult & 24 Jan 2005 & $\mathrm{Y}$ & $\mathrm{Y}$ & $\mathrm{N}$ & 0 \\
\hline MML 0412 & $\mathrm{~F}$ & 238 & 13 & Subadult & 2 Jul 2004 & $\mathrm{~N}$ & $\mathrm{~N}$ & $\mathrm{~N}$ & 0 \\
\hline MML 0413 & $\mathrm{~F}$ & 250 & 14 & Adult & 3 Aug 2004 & $\mathrm{Y}$ & $\mathrm{Y}$ & $\mathrm{N}$ & 0 \\
\hline MML 0511 & $\mathrm{~F}$ & 240 & 16 & Adult & 17 Jun 2005 & $\mathrm{Y}$ & NA & $\mathrm{N}$ & 0 \\
\hline MML 0507 & $\mathrm{M}$ & 262 & 18 & Adult & 8 Mar 2005 & $\mathrm{Y}$ & NA & $\mathrm{Y}$ & 9 \\
\hline MML 0411 & $\mathrm{~F}$ & 258 & 19 & Adult & 13 Jun 2004 & $\mathrm{~N}$ & NA & $\mathrm{N}$ & 0 \\
\hline MML 0502 & $\mathrm{M}$ & 255 & 22 & Adult & 27 Jan 2005 & $\mathrm{~N}$ & $\mathrm{~N}$ & $\mathrm{~N}$ & 0 \\
\hline MML 0409 & $\mathrm{~F}$ & 246 & 23 & Adult & 11 May 2004 & $\mathrm{Y}$ & $\mathrm{Y}$ & $\mathrm{N}$ & 0 \\
\hline MML 0332 & $\mathrm{M}$ & 253 & 25 & Adult & 1 Oct 2003 & $\mathrm{Y}$ & NA & $\mathrm{N}$ & 0 \\
\hline MML 0418 & $\mathrm{M}$ & 262 & 32 & Adult & 1 Nov 2004 & $\mathrm{Y}$ & NA & $\mathrm{N}$ & 0 \\
\hline MML 0416 & $\mathrm{~F}$ & 267 & 34 & Adult & 12 Sep 2004 & $\mathrm{Y}$ & $\mathrm{Y}$ & $\mathrm{N}$ & 0 \\
\hline
\end{tabular}


decomposition of all organs. Of the 15 animals examined histologically, 13 (87\%) had evidence of active or chronic lungworm infection regardless of the gross evidence of nodules (Fig. 2). Thus, gross postmortem prevalence of active or chronic lungworm infection was $77 \%$, whereas, histological prevalence was $87 \%$. Among the age categories, calves had the highest gross postmortem prevalence $(100 \%)$ and neonates had the highest histological prevalence $(100 \%)$. Active infections with intact worms were found in $66 \%$ of the neonates.

Histopathologic lesions varied from subacute bronchopneumonia with intralesional nematodes to multifocal pulmonary fibrosis centered on bronchi/bronchiolar remnants containing intralesional nematode remnants, which corresponded to the lesions interpreted grossly as granulomas. One animal (MML 0408), a stillborn calf, had only small to moderate-sized peribronchial and peribronchiolar aggregates of lymphocytes. In all cases examined histologically, lungworm infection was mild, with a rare moderate case, and was not the primary cause of death.

Subacute lesions consisted of bronchi, bronchioles, and occasional alveolar ducts, with luminal viable nematodes and mild mixed inflammation consisting of

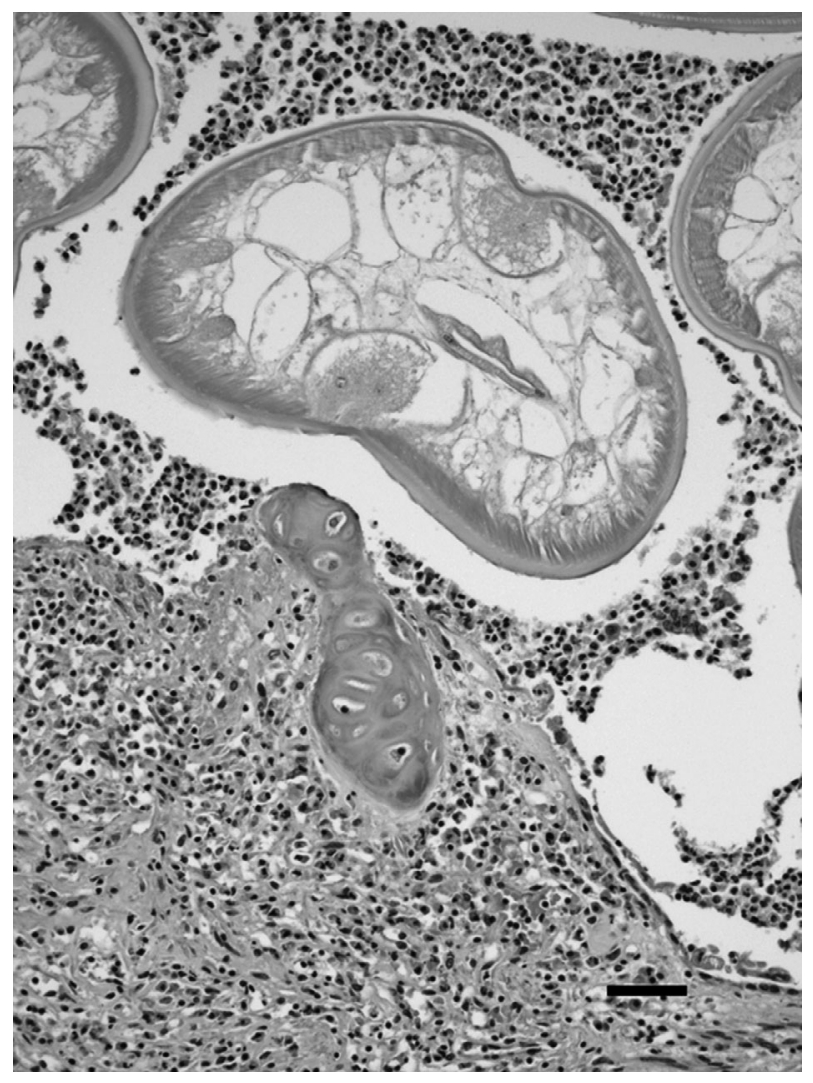

Fig. 2. Tursiops truncatus. Lung histology: subacute bronchiolitis with adult nematode (MML 0409; 20×), scale bar $=50 \mu \mathrm{m}$ macrophages, neutrophils, and eosinophils, with occasional multinucleated giant cells. Bronchial/bronchiolar mucosa had attenuated cells, with loss of cilia, squamous metaplasia, and/or ulceration. The submucosa contained small to rarely moderate multifocal accumulations of lymphocytes, with few plasma cells. In areas of ulceration, neutrophils, macrophages, and eosinophils were also present in the subjacent submucosa. Alveoli adjacent to or surrounding the affected conducting airways were often partially to completely filled with foamy macrophages and/or small to moderate quantities of proteinaceous material. Some alveoli also contained small numbers of nematode larva along with small numbers of neutrophils, eosinophils, and/or multinucleated giant cells.

Chronic lesions were characterized by discrete nodular to broad regions of dense mature fibrous tissue centered on bronchial/bronchiolar remnants, which effaced or distorted the conducting airway and small quantities of surrounding alveolar parenchyma. Central luminal remnants contained necrotic nematodes or nematode fragments and/or small numbers of foamy macrophages, eosinophils, neutrophils, and lymphocytes. Fibrous tissue contained minimal to rarely marked, multifocal accumulations of lymphocytes and plasma cells occasionally with a few eosinophils, neutrophils, and/or macrophages. Adjacent/surrounding alveoli contained small to moderate quantities of proteinaceous fluid and scant to large numbers of foamy macrophages.

A few animals had a mixture of subacute and chronic lesions representing the continuum of lesion maturation from initial conducting airway damage to resolution/granuloma formation. Chronic lesions were noted in all age classes except neonates. All subacute cases were found in neonates. One stillborn animal (MML 0408) had no gross or cytological evidence of lungworm infection, but histologically had a few bronchioles that contained 1 to several 40 to $60 \mu \mathrm{m}$ diameter nematode larvae, with no adults, implying a prepatent infection. The larvae were identified as Halocercus lagenorhynchi. The animal was determined to be stillborn based on morphological findings (fetal folds, rostral hairs, un-erupted teeth) and on histopathology, including pulmonary atelectasis with amniotic squamous cells present in the lungs. Additional pulmonary lesions included pleuritis in 3 adult females and 1 subadult male, and mild subpleural fibrosis and vascular reduplication consistent with angiomatosis in 6 (3 adult, 3 subadult) animals.

Intact worms recovered from the 4 male animals with active infections were examined; in 3 animals the worms were identified as Halocercus lagenorhynchi and in 1 animal the worms were identified as Skrjabinalius cryptocephalus. All worms were sexually 


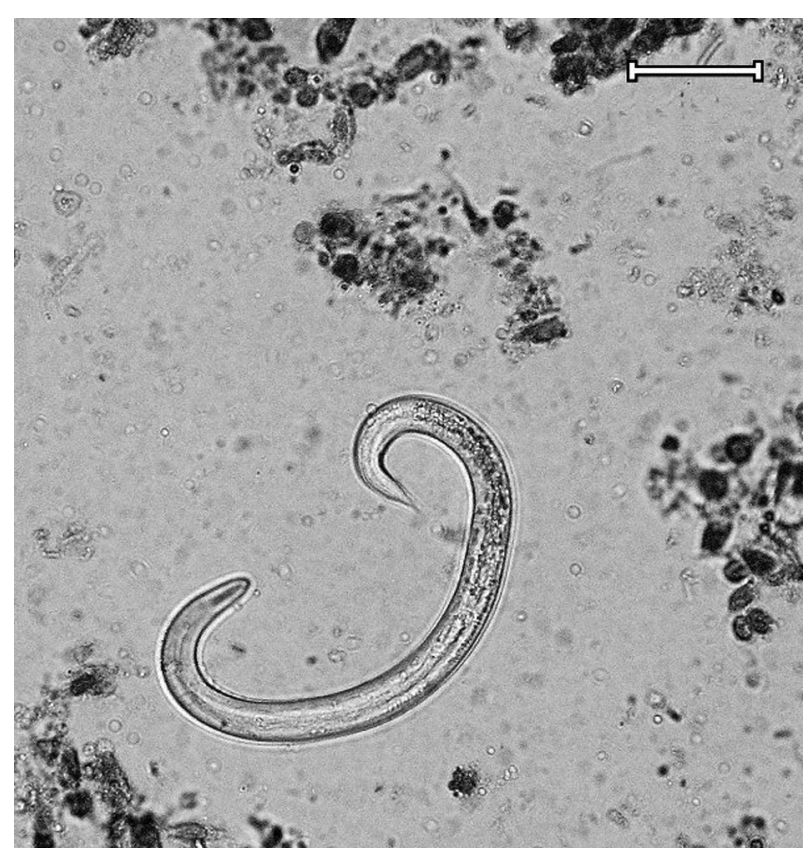

Fig. 3. Tursiops truncatus. Halocercus lagenorhynchi larvae from a tracheal swab (MML 0331; 40×), scale bar $=30 \mu \mathrm{m}$

mature, with female worms present in all 4 dolphins and male worms present in 3 of the 4 dolphins. The intensity of infection ranged from 9 to 59 worms present in the bronchi and lungs of the 4 dolphins, with a geometric mean intensity of infection of 22.6 worms animal $^{-1}$.

Additionally, blowhole swabs, tracheal swabs, and feces were examined in 15 of 22 necropsied animals. Two animals (13\%; MML 0331, MML 0503) were positive for lungworm larvae $(50 \times 700 \mu \mathrm{m})$ on microscopic examination of blowhole and tracheal swabs, indicating patent infections; fecal results were positive on only 1 animal (MML 0503). The larvae were identified as Halocercus lagenorhynchi (Fig. 3).

Forty-four free-ranging bottlenose dolphins were sampled during February and June 2004 and during February and June 2005. Blowhole swabs and fecal samples were collected and evaluated from 44 and 21 animals, respectively. All blowhole samples were negative for lungworm larvae, and only 1 animal was actively shedding lungworm larvae on fecal examination, identified as Halocercus lagenorhynchi. The minimum prevalence of patent lungworm infection in the wild bottlenose dolphin population sampled was $3 \%$.

\section{DISCUSSION}

The present study showed an $87 \%$ prevalence of lungworm infection in bottlenose dolphins Tursiops truncatus based on histological examination, with a decline in prevalence with advancing age. In no instance was lungworm infection the cause of death, and in only 1 calf (CMA 0401) was infection and attendant inflammation severe enough to have been considered of clinical significance. Calves had lesions in transition between active infection and resolution, whereas infections in adults were chronic to resolving in all cases except MML 0507. Neonates were the age class with the most active and severe infections.

Three dolphins with active infections were infected with Halocercus lagenorhynchi, a common lungworm species previously reported in Tursiops truncatus (Dailey et al. 1991). However, 1 animal (MML 0503) was infected with Skrjabinalius cryptocephalus. This species has previously been reported in common dolphins Delphinus delphis from the Black Sea (Delyamure 1955), and a related species, $S$. guevarai, has been reported in bottlenose dolphins from the Mediterranean (Gallego \& Selva 1979). Therefore, the significance of $S$. cryptocephalus in our animal is unclear.

Additionally, intact worms were only recovered from 4 dolphins. We have presumed that worm remnants found in the lungworm granulomas in the remaining chronic cases belong to 1 of these 2 species of worm. However, future molecular work on these lungworm remnants to determine species should be conducted to confirm our suspicions.

The overall sensitivity of blowhole swab and fecal screening for lungworm larvae ranged from 66 to $33 \%$, respectively, in dolphins tested at necropsy. The specificity for both screening methods was $100 \%$. Only animals with active infections and intact worms in the lungs or bronchi had positive screening tests. Therefore, although microscopic examination of blowhole and fecal samples can show active infections, negative results should not be interpreted as an animal being free of infection. Larval shedding in lungworm infections can be sporadic as seen in dogs (Oliveria-Junior et al. 2006), and this irregular pattern appears to occur in the dolphins examined in the present study.

Findings from this lungworm study support the postulation by Dailey et al. (1991) that bottlenose dolphins can be infected transplacentally by lungworms. One stillborn animal (MML 0408) in our study had a prepatent lungworm infection based on histopathology, and in utero infection is the only plausible mechanism for this occurrence. In addition, a neonatal animal (MML 0331) approximately 2 to 4 wk of age had a patent infection (larvae in feces), with intact adult worms observed grossly and histologically.

The impact that transplacental lungworm infection has on neonatal survival is unknown. However, if a neonatal animal is further compromised by a difficult birth or high environmental contaminant loads (Wells et al. 2005), then lungworm infection may be a contrib- 
utory factor in increased neonatal mortality. In conclusion, lungworms are common in coastal bottlenose dolphins from southwestern Florida, are of incidental importance in most age classes, but in young animals infection can cause pneumonia.

Acknowledgements. We thank the staff of the Florida Fish and Wildlife Conservation Commission Marine Mammal Pathobiology Laboratory, especially S. Rommel and A. Costidis for collection of samples, M. Baran and the staff of the Southwest Florida Stranding Network for carcass retrieval, L. Byrd for assistance with cytology, and B. Balmer for preparation of live animal samples. This project was funded by a grant awarded from Harbor Branch Oceanographic Institution, Inc., from proceeds collected from the sale of Protect Wild Dolphins License Plates as authorized by Florida Statute 320.08058(20). Stranding response and postmortem examinations were conducted under a Stranding Agreement from NOAA Fisheries to Mote Marine Laboratory. The health assessment operations in Sarasota Bay were conducted under NOAA Fisheries Scientific Research Permits Nos. 522-1569 and 522-1785, with the support of Dolphin Quest, the National Marine Fisheries Service, and the Chicago Zoological Society.

\section{LITERATURE CITED}

Anderson RC (1978) Keys to genera of the superfamily Metastrongyloidea. In: $\mathrm{CIH}$ keys to the nematode parasites of vertebrates, No. 5. Commonwealth Agricultural Bureaux, Farhham Royal, Bucks, p 1-40

Arnold PW, Gaskin DE (1975) Lungworms (Metastrongyloidea: Pseudaliidae) of harbor porpoise Phocoena phocoena. Can J Zool 53:713-724

Baker JR (1992) Causes of mortality and parasites and incidental lesions in dolphins and whales from British waters. Vet Rec 130:569-572

Balbuena JA, Aspholm PE, Anderson KI, Bjorge A (1994) Lung-worms (Nematoda: Pseudallidae) of harbour porpoises (Phocoena phocoena) in Norwegian waters: patterns of colonization. Parasitology 108:343-349

Cornaglia E, Rebora L, Gili C, Di Guardo G (2000) Histopathological and immunohistochemical studies on cetaceans found stranded on the coast of Italy between 1990 and 1997. J Vet Med A 47:129-142

Dailey MD (1985) Diseases of Mammalia: Cetacea. In: Kinne O (ed) Diseases of marine animals, Vol IV, Part 2. Biologische Anstalt Helgoland, Hamburg, p 805-847

Dailey M, Stroud R (1978) Parasites and associated pathology observed in cetaceans stranded along the Oregon coast. J Wildl Dis 14:503-511

Dailey M, Walsh M, Odell D, Campbell T (1991) Evidence of prenatal infection in the bottlenose dolphin (Tursiops truncatus) with lungworm Halocercus lagenorhynchi (Nema-

Editorial responsibility: Michael Moore, Woods Hole, Massachusetts, USA toda: Pseudaliidae). J Wildl Dis 27:164-165

Delyamure SL (1955) Helminthofauna of marine mammals (ecology and phylogeny). Academy of Sciences of the U.S.S.R. Laboratory of Helminthology (translated by Israel Program for Scientific Translations, Jerusalem, Israel, 1968)

$>$ Faulkner J, Measures LN, Woriskey FG (1998) Stenurus minor (Metastrongyloidea: Pseudaliidae) infections of the cranial sinuses of the harbour porpoise, Phocoena phocoena. Can J Zool 76:1209-1216

Gallego J, Selva JM (1979) Skrjabinalius guevarai n. sp. (Nematoda: Pseudaliidae), parásito pulmonar del delfín mular Tursiops truncatus Montagu, 1821 (Cetacea: Delphinidae) en el Adriático. Rev Iber Parasitol 39:203-208

Geraci JR, Lounsbury VJ (1993) Specimen and data collection. In: Marine mammals ashore: a field guide for strandings. Texas A\&M Sea Grant College Program, Galveston, TX, p 175-228

Hohn A, Scott MD, Wells RS, Sweeney JC, Irvine AB (1989) Growth layers in teeth from known-age free-ranging bottlenose dolphins. Mar Mamm Sci 5:315-342

Jauniaux T, Petitjean D, Brenez C, Borrens M and others (2002) Post-mortem findings and causes of death of harbour porpoises (Phocoena phocoena) stranded from 1990 to 2000 along the coastlines of Belgium and northern France. J Comp Pathol 126:243-253

Measures LN (2001) Lungworms in marine mammals. In: Samuel WM, Pybus MJ, Kocan AA (eds) Parasitic diseases of wild mammals, 2nd edn. Iowa State Press, Ames, IA, p 279-300

Oliveria-Júnior SD, Bracante JMP, Barcante TA, Dias SRC, Lima WS (2006) Larval output of infected and re-infected dogs with Angiostrongylus vasorum (Baillet, 1866) Kamesky, 1905. Vet Parsitol 141:101-106

Parsons ECM, Jefferson TA (2000) Post-mortem investigations on stranded dolphins and porpoises from Hong Kong waters. J Wildl Dis 36:342-356

Read AJ, Wells RS, Hohn AA, Scott MD (1993) Patterns of growth in wild bottlenose dolphins, Tursiops truncatus. J Zool (Lond) 231:107-123

Rowles TK, VanDolah FM, Hohn AA (2001) Gross necropsy and specimen collection protocols. In: Dierauf LA, Gulland FMD (eds) CRC handbook of marine mammal medicine. CRC Press, Boca Raton, FL, p 449-469

> Siebert U, Wunschumann A, Weiss R, Frank H, Benke H, Frese K (2001) Post-mortem findings in harbour porpoises (Phocoena phocoena) from the German North and Baltic Seas. J Comp Pathol 124:102-114

Wells RS, Rhinehart HL, Hansen LJ, Sweeney JC and others (2004) Bottlenose dolphins as marine ecosystem sentinels: developing a health monitoring system. EcoHealth 1: $246-254$

Wells RS, Tornero V, Borrell A, Aguilar A and others (2005) Integrating life history and reproductive success data to examine potential relationships with organochlorine compounds for bottlenose dolphins (Tursiops truncatus) in Sarasota Bay, Florida. Sci Total Environ 349:106-119

Submitted: February 16, 2009; Accepted: May 30, 2009

Proofs received from author(s): December 8, 2009 